\title{
PHYTOCHEMICAL AND BIOLOGICAL STUDY OF ADIANTUM CAPILLUS-VENERIS L. GROWING IN EGYPT
}

\author{
Mahmoud M. Sallam*, Ahmad E. Mostafa , Ezzat A. M. Genady, Said K. Ismail \\ Department of Pharmacognosy, Faculty of Pharmacy, Al-Azhar University, Cairo,
} Egypt.

\section{*Corresponding author: m.sallam@azhar.edu.eg}

\begin{abstract}
Chromatographic fractionation and chemical investigation of the methanolic extract of the fronds and rhizomes of Adiantum capillus-veneris L. (Pteridaceae), resulted in the isolation and identification of four compounds. The structures of the isolated compounds were elucidated using ESI-MS, 1D and 2D (COSY, HSQC and HMBC) NMR experiments, as well as by comparison with literature data. The isolated compounds were identified as; pinoresinol 4- $O-\beta$-D-glucopyranoside (1), pterosterone (2), kampferol-3-O- $\beta$-D-glucuronide (3), and quercetin-3-O- $\beta$-D-glucoside (4). Compounds $\mathbf{1}$ and $\mathbf{2}$ are reported here to be isolated for the first time from family Pteridaceae, however compounds $\mathbf{3}$ and $\mathbf{4}$ were isolated previously from the plant. Total methanolic extract as well as $n$-hexane, ethyl acetate (EtOAc) and $n$-butanol $(n$-BuOH) fractions of A. capillus-veneris L. fern were evaluated for their antidiabetic and antiyeast activity. The four isolated compounds were also evaluated for their anti-yeast activity. The ethyl acetate fraction showed the highest antidiabetic activity. Its inhibitory activity against both $\alpha$-glucosidase and $\alpha$-amylase enzymes was with $\mathrm{IC}_{50}$ values of $52.8 \mu \mathrm{g} / \mathrm{ml}$ and $62.4 \mu \mathrm{g} / \mathrm{ml}$, respectively. The $n$-hexane fraction showed the highest anti-yeast activity.
\end{abstract}

Keywords: Adiantum Capillus-Veneris, Pteridaceae, Antidiabetic, Anti-Yeast, Ecdysteroids, Lignan. 


\section{Introduction}

A. capillus-veneris is a delicate, perennial fern, with a creeping rhizome. It is often found growing on limestone cliffs away from direct sunlight and out of the way of drying southwest winds (Al-Snafi, 2015). It is more effective in fresh condition other than dry however it can also be collected in the summer and dried for later use (Nazim et al., 2018). It has a long history of medicinal use. The fresh or dried leafy fronds had been used as antidandruff, antitussive, astringent, demulcent, depurative, emetic, weakly emmenagogue, emollient, weakly expectorant, febrifuge, galactagogue, laxative, pectoral, refrigerant, stimulant, sudorific and tonic (Ansari and Ekhlasi-Kazaj, 2012; Nazim et al., 2018). It is effective with female conditions and is used to regulate menstruation, dysmenorrhea, and facilitate childbirth (Ansari and Ekhlasi-Kazaj, 2012; Nazim et al., 2018). It also has been used in folk medicine for the management of various diseases such as boils, respiratory problems, diabetes, urinary insufficiency and hepatitis (Ansari and Ekhlasi-Kazaj, 2012; Yumkham et al., 2018). Recent studies demonstrated that the plant exhibits a wide range of biological activities, such as antimicrobial, wound healing, nephroprotective, anti-goitrogenic, antidepressant, anxiolytic and antioxidant activities (Ahmadpoor et al., 2019; Rastogi et al., 2018; Zhang et al., 2019). It was reported that Adiantum capillus-veneris contained flavonoids, triterpenoids, phenylpropanoids, carbohydrates, carotenoids, and alicyclics (Al-Snafi, 2015). The main objective of the present work is to investigate the phytoconstituents, isolation and structure elucidation of the isolated compounds and biological evaluation of $A$. capillus-veneris growing in Egypt. The structures of the isolated compounds were elucidated using ESI-MS, 1D and 2D (COSY, HSQC and HMBC) NMR experiments, as well as by comparison with literature data. The isolated compounds (Fig. 1) were identified as pinoresinol 4-O- $\beta$-D-glucopyranoside (1), pterosterone (2), kampferol-3- $O-\beta$-D-glucuronide (3), and quercetin-3- $O-\beta$-Dglucopyranoside (4). Compounds 1 and $\mathbf{2}$ are reported here to be isolated for the first time from family Pteridaceae.

\section{Experimental \\ General Experimental Procedures}

NMR spectra were recorded on a Bruker Avance NEO-600 instrument at 600 $\left({ }^{1} \mathrm{H}\right)$ and $125\left({ }^{13} \mathrm{C}\right) \mathrm{MHz}$, in DMSO- $d_{6}$ and chemical shifts were expressed in $\delta(\mathrm{ppm})$ with reference to TMS and coupling constant $(J)$ in Hertz. The ESI-MS spectra were measured using a Bruker Bioapex-FTMS with electrospray ionization (ESI). Column chromatographic separation was performed on silica gel $60(0.04-0.063 \mathrm{~mm})$, SPE-C18 Cartridges (Strata USA) and Sephadex LH-20 (0.25-0.1 mm, Aldrich). TLC was performed on precoated TLC plates with silica gel 60 F254 (0.2 mm, Merck).

\section{Plant Material}

The whole fern of A. capillus-veneris was collected in August 2016 from three different localities in Egypt (from Shallalat Garden- Al-Shatby- Alexandria Governorate, from Al-Zohriya Garden- Zamalek- Cairo Governorate and from Qalata, El-Bagour, Menofia Governorate). The plant specimens were kindly authenticated by Mrs. Teresa Labib, Head of Taxonomists at El-Orman Botanical Garden. A voucher specimen (11-2-2016) has been deposited in Pharmacognosy Department, Faculty of Pharmacy, Al-Azhar University, Cairo, Egypt. 


\section{Extraction and isolation}

The air-dried powdered Adiantum capillus-veneris L. fronds and rhizomes (1.5 $\mathrm{kg}$ ) were subjected to exhaustive extraction with $70 \%$ methanol $(3 \times 10 \mathrm{~L})$, at room temperature. The combined methanolic extracts were then concentrated under reduced pressure at $40^{\circ} \mathrm{C}$ to dryness to afford $130.5 \mathrm{~g}$ residue. The concentrated methanolic extract was suspended in distilled water $(500 \mathrm{ml})$ and subjected to fractionation according to the polarity of its active constituents, by using $n$-hexane, EtOAc and $n$ $\mathrm{BuOH}$ to give 34, 1.6 and $19.6 \mathrm{~g}$, respectively. The EtOAc fraction (1.6 g) was subjected to $\mathrm{Si}$ gel $\mathrm{CC}$ eluted with dichloromethane (DCM)-methanol $(\mathrm{MeOH})$ mixtures in a manner of increasing polarities to obtain three subfractions (A1-A3). Subfr. A2 (260 mg) was subjected to sephadex LH-20 eluted with 100\% methanol to obtain five subfractions (A2.1- A2.5). Subfr. A2.2 was subjected to further purification on Si gel CC eluted with DCM-MeOH (100:0-80:20) and sephadex LH-20 eluted with 100\% methanol to obtain compound 1 (14 mg). Subfr. A3 (615 mg) was subjected to Si gel $\mathrm{CC}$ eluted with DCM-MeOH mixtures in a manner of increasing polarities to obtain five subfractions (A3.1- A3.5). Subfr. A3.1 was subjected to reversed solid-phase extraction column (SPE RP C-18) and eluted with Water-MeOH mixtures in a manner of decreasing polarities (100:0-40:60) to afford compound $2(20 \mathrm{mg})$. The $n$-Butanol fraction (19.6 g) was subjected to vacuum liquid chromatography (VLC) fractionation eluted with DCM-MeOH mixtures in a manner of increasing polarities to obtain nine subfractions (B1-B9). Subfr. B4 (1.3 g) was subjected to sephadex LH-20 eluted with $100 \%$ methanol to obtain five subfractions (B4.1-B4.5). Subfr. B4.5 was subjected to further purification on Si gel CC eluted with DCM-MeOH (90:10-70:30) and sephadex LH-20 eluted with 100\% methanol to obtain compound 3 (50 mg). Subfr. B7 (2 g) was subjected to further purification on Si gel CC eluted with DCM-MeOH (90:10-70:30) and sephadex LH-20 eluted with 100\% methanol to obtain compound 4 (25 mg).

\section{Antidiabetic activity:}

\section{Material:}

$\square$-Glucosidase and $\square$-amylase from Saccharomyces cerevisiae (Sigma-Aldrich,

Bangalore).

3,5- dinitro salicylic acid (Sigma-Aldrich, Bangalore).

p-nitro-phenyl- $\square$-D-glucopyranoside (Hi-Media).

Sodium carbonate (Hi-Media).

Sodium dihydrogen phosphate (Hi-Media).

Di-sodium hydrogen phosphate (Hi-Media).

\section{Method:}

The antidiabetic activity of $A$. capillus-veneris $\mathrm{L}$. total extract and different fractions was carried out according to the standard methods with minor modification (Narkhede et al., 2011; Shai et al., 2011). In a 96-well plate, reaction mixture containing $50 \mu \mathrm{l}$ phosphate buffer $(100 \mathrm{mM}, \mathrm{pH}=6.8), 10 \mu \mathrm{l} \alpha$-glucosidase $(1 \mathrm{U} / \mathrm{ml})$, and $20 \mu \mathrm{l}$ of varying concentrations of extracts and fractions $(1000$ to $7.81 \mu \mathrm{g} / \mathrm{mL})$ was preincubated at $37^{\circ} \mathrm{C}$ for $15 \mathrm{~min}$. Then, $20 \mu \mathrm{p}$-NPG $(5 \mathrm{mM})$ was added as a substrate and incubated further at $37^{\circ} \mathrm{C}$ for $20 \mathrm{~min}$. The reaction was stopped by adding $50 \mu \mathrm{l} \mathrm{Na} \mathrm{CO}_{3}(0.1 \mathrm{M})$. The absorbance of the released $p$-nitrophenol was measured at $405 \mathrm{~nm}$ using Multiplate Reader. Acarbose at various concentrations $(1000$ to $7.81 \mu \mathrm{g} / \mathrm{mL})$ was included as a standard. Without test substance was set up in parallel as a control and each experiment 
was performed in triplicates. In $\alpha$-amylase inhibition method, the enzyme solution was prepared by dissolving $\alpha$-amylase in $20 \mathrm{mM}$ phosphate buffer $(\mathrm{pH} 6.9$ ) at the concentration of $0.5 \mathrm{mg} / \mathrm{ml} .1 \mathrm{ml}$ of the extract of various concentrations $(1000-7.81$ $\mu \mathrm{g} / \mathrm{ml}$ ) and $1 \mathrm{ml}$ of enzyme solution were mixed together and incubated at $25^{\circ} \mathrm{C}$ for $10 \mathrm{~min}$. After incubation, $1 \mathrm{ml}$ of starch $(0.5 \%)$ solution was added to the mixture and further incubated at $25^{\circ} \mathrm{C}$ for $10 \mathrm{~min}$. The reaction was then stopped by adding $2 \mathrm{ml}$ of dinitro salicylic acid (DNS, color reagent), heating the reaction mixture in a boiling water bath $(5 \mathrm{~min})$. After cooling, the absorbance was measured colorimetrically at 565 nm.

The results were expressed as percentage inhibition, which was calculated using the formula: Inhibitory activity $(\%)=(1-\mathrm{As} / \mathrm{Ac}) \times 100$, where, As is the absorbance in the presence of test substance and $\mathrm{Ac}$ is the absorbance of control. The $\mathrm{IC}_{50}$ value was defined as the concentration of $\alpha$-glucosidase inhibitor to inhibit $50 \%$ of the enzyme activity under the assay conditions.

\section{Anti-yeast activity:}

\section{Media used:}

YPD media: A complex media used for routine yeast growth. It contains yeast extract, peptone and glucose.

SC media: A synthetic complete media used for yeast growth.

SC+HEPES media: A synthetic complete media with HEPES (4-(2-hydroxyethyl)-1piperazinethanesulfonic acid) buffer.

\section{Method:}

The anti-yeast activity of $A$. capillus-veneris $\mathrm{L}$. total extract and different fractions as well as the isolated compounds (1-4) was carried out using Bar-Seq protocol (Smith et al., 2009). It aimed to screen Saccharomyces cerevisiae pdr1/3 deletion library for deletion mutants that are hypersensitive to a compound or extract. First, microtiter growth inhibition assay was performed, and the MIC was established in 96 well plate over 16-18 h. The deletion library screen was done by incubating the pooled library in a concentration of compound that inhibits growth by $10-25 \%$ over the course of the assay. The screen was performed in two stages in a 24 well plate incubated with shaking at $30{ }^{\circ} \mathrm{C}$ :

Stage 1: $\quad 12 \mathrm{~h}$ incubation with shaking.

Stage 2: $\quad$ The growth of the cultures was measured on the plate reader after 12 $\mathrm{h}$ and they are re-inoculated into the same concentration(s) at the same density as the start of the first phase. Cultures were incubated with shaking for a further $10 \mathrm{~h}$. After $10 \mathrm{~h}$ the final growth was measured on the plate reader.

Most compounds are less effective at inhibiting the growth of the pool in the 24 well plate when shaken. Therefore, the appropriate compound concentration (that inhibits growth by 10-25\% over the course of the screen) is often higher than the $16 \mathrm{~h}$ 96 well plate MIC. A range of concentrations (3-4) that span the MIC was chosen. The growth was measured after the stage one $12 \mathrm{~h}$ incubation. The concentration of compound that will inhibit 10-25\% at the end of stage 2 will inhibit by $\sim 60 \%$ after 12 
h. Compounds were screened in triplicate with DMSO at $1 \% .1 \%$ DMSO was used as negative control and YPD as a Blank.

\section{Results and Discussion Compound 1}

was obtained as colorless crystals (14 mg), it gave dark color under UV (365 $\mathrm{nm}$ ) and gave violet color on the TLC plate when sprayed with Vanillin $\backslash \mathrm{H}_{2} \mathrm{SO}_{4}$ reagent followed by $2 \mathrm{~min}$ heating at $150{ }^{\circ} \mathrm{C}$ with $R_{f}$ value $=0.62$ using solvent system DCM:MeOH (85:15). Its molecular formula was established to be $\mathrm{C}_{26} \mathrm{H}_{32} \mathrm{O}_{11}$ from the $[\mathrm{M}+\mathrm{Na}]^{+}$ion at $\mathrm{m} / \mathrm{z} 543$, in the ESI-MS. The HMBC and COSY correlations of compound 1 (Fig. 2) showed a set of correlations that confirmed the suggested structure. ${ }^{1} \mathrm{H}$, APT, COSY and HMBC NMR spectral data for compound $\mathbf{1}$ are summarized in Table 1. On the basis of the obtained data, and by comparing with reported literature (Chiba et al., 1980; Diep et al., 2007; Ouyang et al., 2007; Yue et al., 2013; Zhou et al., 2009), compound 1 was identified as pinoresinol 4- $O-\beta$-Dglucopyranoside.

\section{Compound 2}

was obtained as colorless prisms (20 mg), it gave dark color under UV (365 nm) and gave an emerald green color with Vanillin $\backslash \mathrm{H}_{2} \mathrm{SO}_{4}$ reagent which turned into grey after 2 min heating at $150{ }^{\circ} \mathrm{C}$ with $R_{f}$ value $=0.78$ using system DCM:MeOH (80:20). ESI-MS spectrum (positive-ion mode) of 2 exhibited a pseudomolecular ion peak at $\mathrm{m} / \mathrm{z}$ $519[\mathrm{M}+\mathrm{K}]^{+}$, indicating a molecular weight of 480 , consistent with a molecular formula $\mathrm{C}_{27} \mathrm{H}_{44} \mathrm{O}_{7}$. The HMBC and COSY correlations of compound 2 (Fig. 3) showed a set of correlations that confirmed the suggested structure. ${ }^{1} \mathrm{H}$, APT, COSY and HMBC NMR spectral data for compound $\mathbf{2}$ in are summarized in Table 2. Thus, the structure of $\mathbf{2}$ proved to be the ecdysteroid pterosterone and its data was in a good agreement with the reported literature (Blunt et al., 1979; Coll et al., 1994; Dziwornu et al., 2017; Nishimoto et al., 1987; Ohta et al., 1996).

\section{Compound 3}

was isolated as yellow amorphous powder $(50 \mathrm{mg})$, it gave dark color under UV (365 nm), changed to intense yellow color after exposure to ammonia vapors. It gave one spot on TLC with $R_{f}=0.58$ using solvent system DCM: $\mathrm{MeOH}: \mathrm{H}_{2} \mathrm{O}$ (61:32:7). ESIMS analysis showed an [2M-H] $]^{-}$ion at $\mathrm{m} / z, 923$ and $[\mathrm{M}-\mathrm{H}]^{-}$ion at $\mathrm{m} / z, 461$, which was consistent with the formula $\mathrm{C}_{21} \mathrm{H}_{18} \mathrm{O}_{12}$. Another fragment ion peak at $\mathrm{m} / z 285$ obtained after loss of $176 \mathrm{amu}$ (glucurone unit). ${ }^{1} \mathrm{H}, \mathrm{APT}, \mathrm{COSY}$ and HMBC NMR spectral data for compound 3 in are summarized in Table 3. On the basis of the obtained data, and by comparing with the reported literature (Harborne, 1994; Kajdžanoska et al., 2010; Nawwar et al., 1984), compound 3 was identified as kampferol-3-O- $\square$-D-glucuronide.

\section{Compound 4}

was isolated as pale-yellow amorphous powder $(25 \mathrm{mg})$, it gave dark color under UV (365 nm), changed to intense yellow color after exposing the TLC plate to ammonia vapors. It gave one spot on TLC with $R_{f}=0.6$ using solvent system DCM: $\mathrm{MeOH}: \mathrm{H}_{2} \mathrm{O}$ (80:20:2). ESI-MS analysis showed an $[\mathrm{M}+\mathrm{K}]^{+}$ion at $\mathrm{m} / z, 503$ and $[\mathrm{M}-\mathrm{H}]^{-}$ion at $\mathrm{m} / \mathrm{z}$ 463 , consistent with the formula $\mathrm{C}_{21} \mathrm{H}_{20} \mathrm{O}_{12}$. Another fragment ion peak at $\mathrm{m} / z, 302$ indicated the loss of a hexose unit (162 amu). ${ }^{1} \mathrm{H}$, APT, COSY and HMBC NMR spectral data for compound 4 in are summarized in Table 4. On the basis of the obtained data, and by comparing with the reported literature (Harborne, 1994; Liu et al., 
2010), compound 4 was identified as quercetin-3- $O$ - $\square$-D-glucopyranoside (Isoquercitrin).

Table 1: $1 \mathrm{D}$ and 2D NMR spectral data $\left(600 \mathrm{MHz}\right.$ for $\delta_{\mathrm{H}}, 125 \mathrm{MHz}$ for $\delta_{\mathrm{C}}$ ) for compound 1 in DMSO- $d_{6}$

\begin{tabular}{|c|c|c|c|c|c|}
\hline Position & $\delta_{\mathbf{H}}(J, \mathbf{H z})$ & $\boldsymbol{\delta}_{\mathbf{C}}$ & APT & COSY & HMBC \\
\hline \multicolumn{6}{|l|}{ Aglycone } \\
\hline 1 & & 135.79 & $\mathrm{C}$ & & \\
\hline 2 & $6.95 \mathrm{~d}, 1.8$ & 111.13 & $\mathrm{CH}$ & & C-4, C-6, C-7 \\
\hline 3 & & 149.51 & $\mathrm{C}$ & & \\
\hline 4 & & 146.51 & $\mathrm{C}$ & & \\
\hline 5 & $7.04 \mathrm{~d}, 8.4$ & 115.77 & $\mathrm{CH}$ & H-6 & $\mathrm{C}-1, \mathrm{C}-3, \mathrm{C}-4$ \\
\hline 6 & $6.85 \mathrm{dd}, 8.4,1.8$ & 118.71 & $\mathrm{CH}$ & $\mathrm{H}-5$ & C-2, C-4, C-7 \\
\hline 7 & $4.61 \mathrm{~d}, 4.2$ & 85.45 & $\mathrm{CH}$ & $\mathrm{H}-8$ & C-2, C-6, C-8, C-9' \\
\hline 8 & $3.04 \mathrm{~m}$ & 54.30 & $\mathrm{CH}$ & $\mathrm{H}-7, \mathrm{H}-9$ & \\
\hline $9 \mathrm{a}$ & $3.75 \mathrm{dd}, 9.0,3.6$ & 71.60 & $\mathrm{CH}_{2}$ & H-8 & C-8, C-7' \\
\hline $9 \mathrm{~b}$ & $4.14 \mathrm{dd}, 9.0,7.2$ & & & & \\
\hline $\mathrm{OCH}_{3}$ & $3.77 \mathrm{~s}$ & 56.28 & $\mathrm{CH}_{3}$ & & $\mathrm{C}-3$ \\
\hline $1^{\prime}$ & & 132.76 & $\mathrm{C}$ & & \\
\hline $2^{\prime}$ & $6.89 \mathrm{~d}, 1.8$ & 110.99 & $\mathrm{CH}$ & & C-4', C-6', C-7' \\
\hline 31 & & 148.11 & $\mathrm{C}$ & & \\
\hline $4^{\prime}$ & & 146.42 & $\mathrm{C}$ & & \\
\hline $5^{\prime}$ & $6.72 \mathrm{~d}, 8.4$ & 115.7 & $\mathrm{CH}$ & & $\mathrm{C}-1$ ', C-3' \\
\hline $6 \prime$ & $6.75 \mathrm{dd}, 8.4,1.8$ & 119.23 & $\mathrm{CH}$ & & C-2 ', C-4', C-7' \\
\hline $7^{\prime}$ & $4.67 \mathrm{~d}, 4.2$ & 85.75 & $\mathrm{CH}$ & H-8' & C-2', C-6', C-8', C-9 \\
\hline $8^{\prime}$ & $3.04 \mathrm{~m}$ & 54.15 & $\mathrm{CH}$ & H-7 ', H-9' & \\
\hline $9_{\mathrm{a}}^{\prime}$ & $3.75 \mathrm{dd}, 9.0,3.6$ & 71.52 & $\mathrm{CH}_{2}$ & H-8' & $\mathrm{C}-8^{\prime}, \mathrm{C}-7$ \\
\hline $9_{\mathrm{b}}^{\prime}$ & $4.13 \mathrm{dd}, 9.0,7.2$ & & & & \\
\hline $\mathrm{OCH}_{3}{ }^{\prime}$ & $3.76 \mathrm{~s}$ & 56.19 & $\mathrm{CH}_{3}$ & & $\mathrm{C}-3^{\prime}$ \\
\hline \multicolumn{6}{|l|}{ Glc } \\
\hline $1 "$ & $4.87 \mathrm{~d}, 7.5$ & 100.72 & $\mathrm{CH}$ & H-2" & C-4 \\
\hline $2 "$ & $3.24 \mathrm{~m}$ & 73.79 & $\mathrm{CH}$ & & \\
\hline 3" & $3.25 \mathrm{~m}$ & 77.44 & $\mathrm{CH}$ & & \\
\hline 4" & $3.15 \mathrm{~m}$ & 70.26 & $\mathrm{CH}$ & & \\
\hline $5 "$ & $3.27, \mathrm{~m}$ & 77.62 & $\mathrm{CH}$ & & \\
\hline $6{ }_{a}$ & $3.66 \mathrm{dd}, 12.0,1.8$ & 61.26 & $\mathrm{CH}_{2}$ & & \\
\hline $6 "_{b}$ & $3.44 \mathrm{dd}, 12.0,5.4$ & & & & \\
\hline
\end{tabular}


Table 2: $1 \mathrm{D}$ and 2D NMR spectral data $\left(600 \mathrm{MHz}\right.$ for $\delta_{\mathrm{H}}, 125 \mathrm{MHz}$ for $\delta_{\mathrm{C}}$ ) for compound 2 in DMSO- $d_{6}$

\begin{tabular}{|c|c|c|c|c|c|}
\hline Position & $\boldsymbol{\delta}_{\mathbf{H}}(J, \mathrm{~Hz})$ & $\boldsymbol{\delta}_{\mathbf{C}}$ & APT & COSY & $\mathrm{HMBC}$ \\
\hline 1 & $1.22 \mathrm{~m}, 1.52 \mathrm{~m}$ & 35.32 & $\mathrm{CH}_{2}$ & $\mathrm{H}-2$ & C-2, C-10, C-19 \\
\hline 2 & $3.60 \mathrm{brs}$ & 66.78 & $\mathrm{CH}$ & $\mathrm{H}-1, \mathrm{H}-3$ & \\
\hline 3 & 3.76 brs & 66.58 & $\mathrm{CH}$ & H-2, H-4 & \\
\hline 4 & $1.48 \mathrm{~m}, 1.77 \mathrm{~m}$ & 30.33 & $\mathrm{CH}_{2}$ & $\mathrm{H}-3, \mathrm{H}-5$ & \\
\hline 5 & $2.20 \mathrm{~m}$ & 50.11 & $\mathrm{CH}$ & $\mathrm{H}-4$ & $\mathrm{C}-6$ \\
\hline 6 & - & 202.68 & $\mathrm{C}$ & - & \\
\hline 7 & $5.62 \mathrm{~d}, 1.8$ & 120.44 & $\mathrm{CH}$ & H-9 & C-5, C-9, C-14 \\
\hline 8 & - & 165.17 & $\mathrm{C}$ & - & \\
\hline 9 & $3.01 \mathrm{~m}$ & 31.78 & $\mathrm{CH}$ & H-11 & $\mathrm{C}-7$ \\
\hline 10 & - & 37.62 & $\mathrm{C}$ & - & \\
\hline 11 & $1.53 \mathrm{~m}, 1.63 \mathrm{~m}$ & 20.08 & $\mathrm{CH}_{2}$ & H-9, H-12 & \\
\hline 12 & $1.71 \mathrm{~m}, 2.0 \mathrm{~m}$ & 30.85 & $\mathrm{CH}_{2}$ & H-11 & \\
\hline 13 & - & 46.88 & $\mathrm{C}$ & - & \\
\hline 14 & - & 82.94 & $\mathrm{C}$ & - & \\
\hline 15 & $1.46 \mathrm{~m}, 1.58 \mathrm{~m}$ & 31.56 & $\mathrm{CH}_{2}$ & & \\
\hline 16 & $1.64 \mathrm{~m}, 1.88 \mathrm{~m}$ & 20.29 & $\mathrm{CH}_{2}$ & $\mathrm{H}-17$ & \\
\hline 17 & $2.20 \mathrm{~m}$ & 48.56 & $\mathrm{CH}$ & H-16 & $\mathrm{C}-13, \mathrm{C}-15, \mathrm{C}-16, \mathrm{C}-18$ \\
\hline 18 & $0.76 \mathrm{~s}$ & 17.14 & $\mathrm{CH}_{3}$ & - & $\mathrm{C}-12, \mathrm{C}-14, \mathrm{C}-17$ \\
\hline 19 & $0.83 \mathrm{~s}$ & 23.89 & $\mathrm{CH}_{3}$ & - & C-5, C-9, C-10 \\
\hline 20 & - & 75.56 & $\mathrm{C}$ & - & \\
\hline 21 & $1.08 \mathrm{~s}$ & 20.95 & $\mathrm{CH}_{3}$ & & $\mathrm{C}-17, \mathrm{C}-20$ \\
\hline 22 & $3.67 \mathrm{~m}$ & 73.96 & $\mathrm{CH}$ & $\mathrm{H}-23$ & $\mathrm{C}-17, \mathrm{C}-20$ \\
\hline 23 & $1.26 \mathrm{~m}, 1.59 \mathrm{~m}$ & 35.32 & $\mathrm{CH}_{2}$ & H-22, H-24 & \\
\hline 24 & $3.30 \mathrm{~m}$ & 75.01 & $\mathrm{CH}$ & $\mathrm{H}-23$ & \\
\hline 25 & $1.60 \mathrm{~m}$ & 31.78 & $\mathrm{CH}$ & H-26, H-27 & \\
\hline 26 & $0.79 \mathrm{~d}, 6.6$ & 16.07 & $\mathrm{CH}_{3}$ & H-25 & $\mathrm{C}-24, \mathrm{C}-25, \mathrm{C}-27$ \\
\hline 27 & $0.86 \mathrm{~d}, 6.6$ & 19.45 & $\mathrm{CH}_{3}$ & $\mathrm{H}-25$ & $\mathrm{C}-24, \mathrm{C}-25, \mathrm{C}-26$ \\
\hline
\end{tabular}


Table 3: $1 \mathrm{D}$ and 2D NMR spectral data $\left(600 \mathrm{MHz}\right.$ for $\delta_{\mathrm{H}}, 125 \mathrm{MHz}$ for $\left.\delta_{\mathrm{C}}\right)$ of 3 in DMSO- $d_{6}$.

\begin{tabular}{|c|c|c|c|c|c|}
\hline Position & $\delta_{\mathrm{H}}(J, \mathrm{~Hz})$ & $\delta_{\mathrm{C}}$ & APT & COSY & HMBC \\
\hline \multicolumn{6}{|l|}{ Aglycone } \\
\hline 2 & - & 156.22 & $\mathrm{C}$ & - & - \\
\hline 3 & - & 132.96 & $\mathrm{C}$ & - & - \\
\hline 4 & - & 177.33 & $\mathrm{C}$ & - & - \\
\hline 5 & - & 160.98 & $\mathrm{C}$ & - & - \\
\hline 6 & $6.04 \mathrm{~d}, 1.8$ & 98.54 & $\mathrm{CH}$ & - & C-8, C-10 \\
\hline 7 & - & 164.51 & $\mathrm{C}$ & - & - \\
\hline 8 & $6.25 \mathrm{~d}, 1.8$ & 93.70 & $\mathrm{CH}$ & - & C-6, C-10 \\
\hline 9 & - & 156.25 & $\mathrm{C}$ & - & - \\
\hline 10 & - & 103.60 & $\mathrm{C}$ & - & - \\
\hline $1^{\prime}$ & - & 120.92 & $\mathrm{C}$ & - & - \\
\hline $2^{\prime}$ & $8.01 \mathrm{~d}, 9.0$ & 130.95 & $\mathrm{CH}$ & H-3' & C-2, C-4', C-6' \\
\hline $3^{\prime}$ & $6.83 \mathrm{~d}, 9.0$ & 114.95 & $\mathrm{CH}$ & H-2' & $\mathrm{C}-1^{\prime}, \mathrm{C}-4^{\prime}, \mathrm{C}-5^{\prime}$ \\
\hline $4^{\prime}$ & - & 159.91 & $\mathrm{C}$ & - & - \\
\hline $5^{\prime}$ & $6.83 \mathrm{~d}, 9.0$ & 114.95 & $\mathrm{CH}$ & H-6' & C-1', C-3', C-4' \\
\hline $6^{\prime}$ & $8.01 \mathrm{~d}, 9.0$ & 130.95 & $\mathrm{CH}$ & H-5' & $\mathrm{C}-2, \mathrm{C}-2^{\prime}, \mathrm{C}-4^{\prime}$ \\
\hline \multicolumn{6}{|l|}{ GlcA } \\
\hline $1 "$ & $5.53 \mathrm{~d}, 7.8$ & 100.77 & $\mathrm{CH}$ & H-2" & $\mathrm{C}-3, \mathrm{C}-2^{\prime \prime}$ \\
\hline $2 "$ & $3.15-3.57^{\mathrm{a}}$ & 74.09 & $\mathrm{CH}$ & & \\
\hline $3 "$ & $3.15-3.57^{\mathrm{a}}$ & 76.34 & $\mathrm{CH}$ & & \\
\hline $4 "$ & $3.15-3.57^{\mathrm{a}}$ & 72.05 & $\mathrm{CH}$ & & \\
\hline $5 "$ & $3.15-3.57^{\mathrm{a}}$ & 74.28 & $\mathrm{CH}$ & & \\
\hline $6 "$ & - & 171.80 & $\mathrm{C}$ & - & - \\
\hline 5-OH & 12.48 brs & & & & \\
\hline
\end{tabular}

${ }^{\mathrm{a}}$ overlapped signals. 
Table 4: $1 \mathrm{D}$ and 2D NMR NMR spectral data $\left(600 \mathrm{MHz}\right.$ for $\delta_{\mathrm{H}}, 125 \mathrm{MHz}$ for $\left.\delta_{\mathrm{C}}\right)$ of 4 in DMSO- $d_{6}$.

\begin{tabular}{|c|c|c|c|c|c|}
\hline Position & $\overline{\delta_{\mathrm{H}}(J, \mathrm{~Hz})}$ & $\delta_{\mathrm{C}}$ & APT & COSY & HMBC \\
\hline \multicolumn{6}{|l|}{ Aglycone } \\
\hline 2 & - & 156.11 & $\mathrm{C}$ & - & - \\
\hline 3 & - & 133.28 & $\mathrm{C}$ & - & - \\
\hline 4 & - & 177.35 & $\mathrm{C}$ & - & - \\
\hline 5 & - & 161.22 & $\mathrm{C}$ & - & - \\
\hline 6 & 6.17 brs & 98.84 & $\mathrm{CH}$ & - & $\mathrm{C}-8, \mathrm{C}-10$ \\
\hline 7 & - & 164.59 & $\mathrm{C}$ & - & - \\
\hline 8 & $6.38 \mathrm{brs}$ & 93.61 & $\mathrm{CH}$ & - & C-6, C-10 \\
\hline 9 & - & 156.37 & $\mathrm{C}$ & - & - \\
\hline 10 & - & 103.84 & $\mathrm{C}$ & - & - \\
\hline $1^{\prime}$ & - & 121.08 & $\mathrm{C}$ & - & - \\
\hline $2^{\prime}$ & $7.58 \mathrm{~d}, 2.4$ & 116.12 & $\mathrm{CH}$ & - & C-2, C-3', C-4', C-6' \\
\hline $3^{\prime}$ & - & 144.86 & $\mathrm{C}$ & - & - \\
\hline $4^{\prime}$ & - & 148.54 & $\mathrm{C}$ & - & - \\
\hline $5^{\prime}$ & $6.83 \mathrm{~d}, 9.0$ & 115.21 & $\mathrm{CH}$ & H-6' & C-3', C-4', C-6' \\
\hline $6{ }^{\prime}$ & $7.56 \mathrm{dd}, 9.0,2.4$ & 121.61 & $\mathrm{CH}$ & H-5' & C-2, C-4', C-5' \\
\hline \multicolumn{6}{|l|}{ Glc } \\
\hline $1 "$ & $5.44 \mathrm{~d}, 7.2$ & 100.91 & $\mathrm{CH}$ & H-2" & \\
\hline $2 "$ & $3.23, \mathrm{~m}$ & 74.10 & $\mathrm{CH}$ & H-1" & C-1", C-3" \\
\hline $3 "$ & $3.22, \mathrm{~m}$ & 77.58 & $\mathrm{CH}$ & & C-4" \\
\hline $4 "$ & $3.09, \mathrm{~m}$ & 69.94 & $\mathrm{CH}$ & & C-3" \\
\hline $5 "$ & $3.08, \mathrm{~m}$ & 76.52 & $\mathrm{CH}$ & & \\
\hline $6{ }_{a}$ & 3.58 br d, 11.4 & 60.98 & $\mathrm{CH}_{2}$ & & C-4" \\
\hline $6 "_{\mathrm{b}}$ & 3.33 overlapped & & & & \\
\hline 5-OH & 12.62 brs & & & & \\
\hline
\end{tabular}




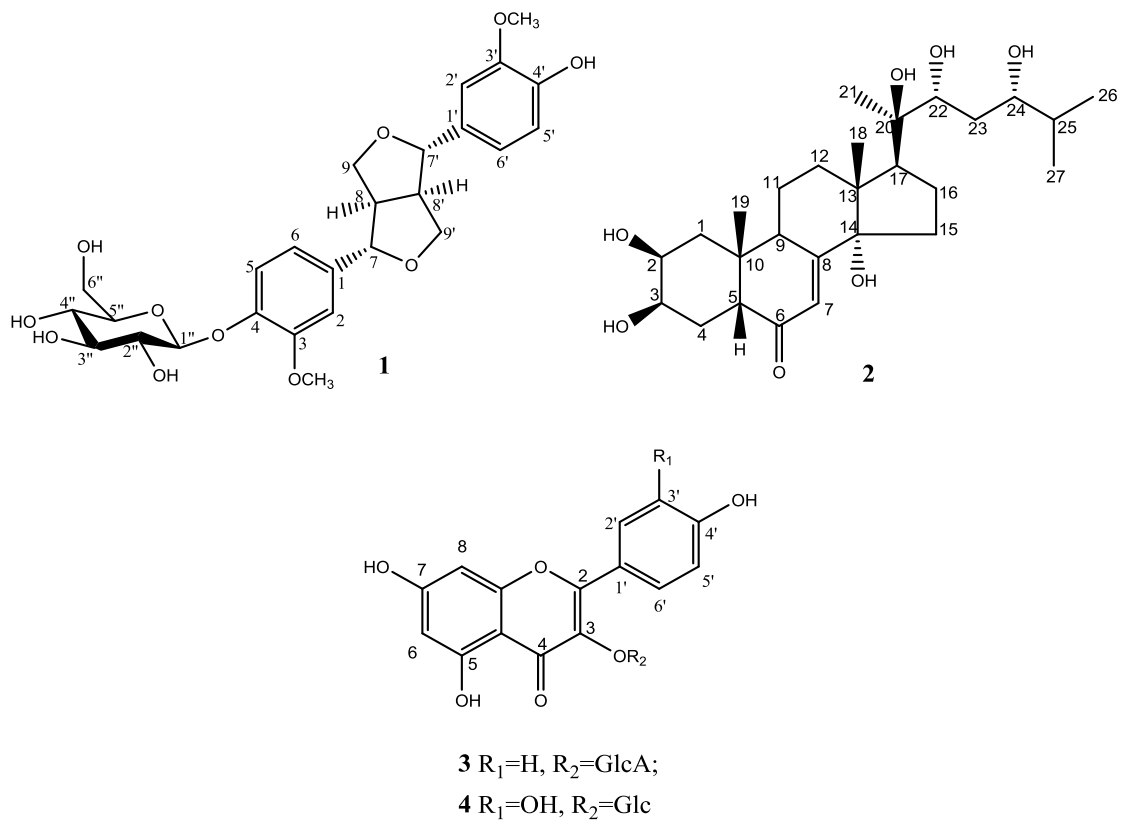

Fig. 1: The structures of 1-4

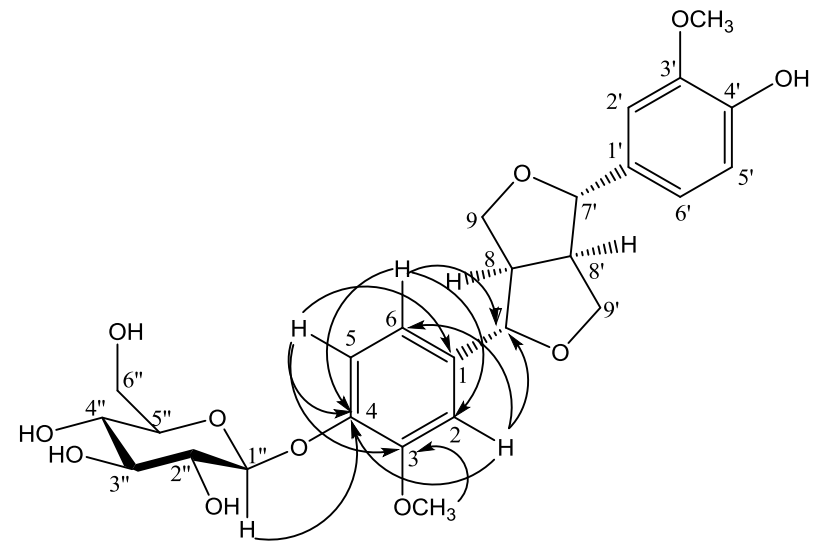

Fig. 3: Key correlations of COSY ( $)$ and $\operatorname{HMBC}(\frown)$ ) for 2.

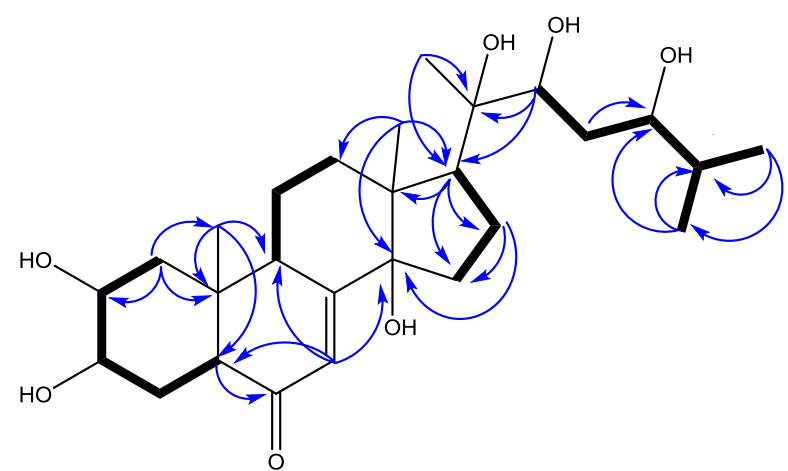

Fig. 2: Key HMBC correlations observed for $\mathbf{1}$. 


\section{Anti-diabetic activity:}

The total extract and different fractions of Adiantum capillus-veneris fronds and rhizomes were tested against $\alpha$-glucosidase and $\alpha$-amylase enzymes at different concentrations (1000-7.81 $\mu \mathrm{g} / \mathrm{ml})$ and compared with Acarbose as a standard drug. The EtOAc fraction showed a remarkable inhibitory activity against both $\alpha$-glucosidase and $\alpha$-amylase enzymes with $\mathrm{IC}_{50}=52.8 \mu \mathrm{g} / \mathrm{ml}$ and $62.4 \mu \mathrm{g} / \mathrm{ml}$, respectively (Figures 4-6, Tables 5 and 6). The hypoglycemic effects of the EtOAc fraction may be due to the presence of flavonoids, lignins and/or phytoecdysteroids which are known for their hypoglycemic effects (Bajguz et al., 2015; Rasouli et al., 2017; Subramoniam, 2016; Wikul et al., 2012; Worawalai et al., 2016) .

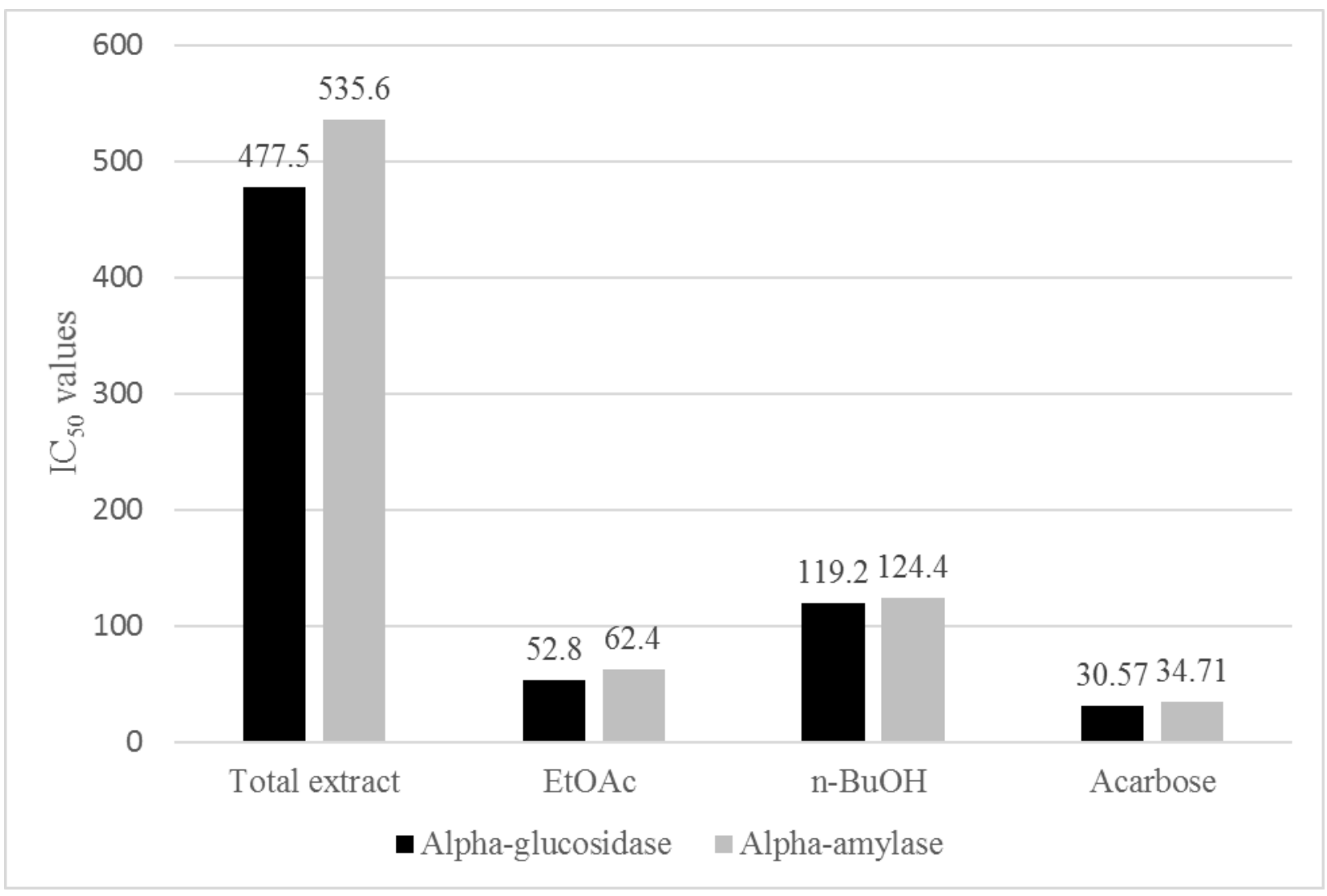

Fig. 4: $\mathrm{IC}_{50}$ values $(\mu \mathrm{g} / \mathrm{ml})$ of $A$. capillus-veneris total extract and different fractions against $\alpha$-glucosidase and $\alpha$-amylase enzymes. 
Table 5: $\alpha$-glucosidase inhibitory $\%$ of EtOAc fraction and acarbose.

\begin{tabular}{ccccc}
$\begin{array}{c}\text { Sample } \\
\text { conc. } \\
(\mu \mathrm{g} / \mathrm{ml})\end{array}$ & $\begin{array}{c}\text { Mean of } \alpha \text {-glucosidase } \\
\text { inhibitory \% of EtOAc } \\
\text { fraction }\end{array}$ & S.D. & $\begin{array}{c}\text { Mean of } \alpha \text {-glucosidase } \\
\text { inhibitory } \% \text { of } \\
\text { acarbose }\end{array}$ & S.D. \\
\hline 1000 & 82.15 & 1.2 & 90.10 & 0.58 \\
\hline 500 & 74.63 & 1.5 & 86.34 & 1.2 \\
\hline 250 & 69.25 & 0.58 & 71.34 & 1.5 \\
\hline 125 & 60.14 & 0.92 & 63.42 & 2.1 \\
\hline 62.5 & 56.14 & 0.36 & 60.14 & 0.72 \\
\hline 31.25 & 36.37 & 1.5 & 50.31 & 1.5 \\
\hline 15.63 & 29.42 & 0.71 & 43.28 & 1.2 \\
\hline 7.81 & 16.35 & 1.6 & 32.15 & 0.58 \\
\hline 0 & 0 & 0 & 0 & 0 \\
\hline $\mathrm{IC}_{50}$ & 52.8 & & 30.57 &
\end{tabular}

All determinations were carried out in triplicate manner and values are expressed as the mean $\pm \mathrm{SD}$. The $\mathrm{IC}_{50}$ value is defined as the concentration of inhibitor to inhibit $50 \%$ of the enzyme activity under the assayed conditions.

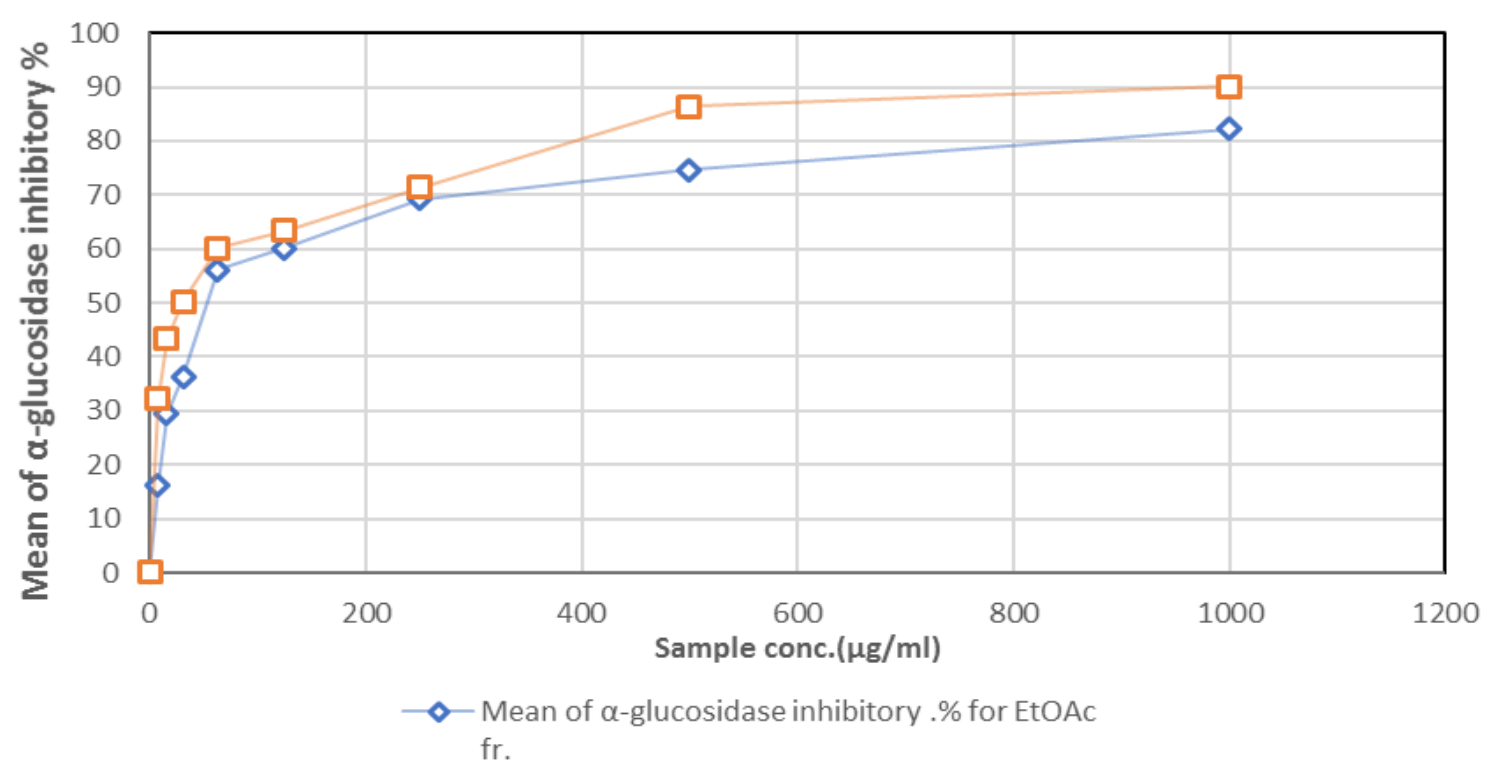

Fig. 5: $\alpha$-glucosidase inhibitory $\%$ for EtOAc fr. and Acarbose. 
Table 6: $\alpha$-amylase inhibitory \% of EtOAc fraction and acarbose

Sample conc. Mean of $\alpha$-amylase $(\mu \mathrm{g} / \mathrm{ml})$ inhibitory \% of EtOAc fraction
S.D. Mean of $\alpha$-amylase inhibitory $\%$ of acarbose
S.D.

\begin{tabular}{ccccc}
\hline 1000 & 73.63 & 0.63 & 86.32 & 0.63 \\
\hline 500 & 68.34 & 1.2 & 80.14 & 0.58 \\
\hline 250 & 61.37 & 0.72 & 69.37 & 1.2 \\
\hline 125 & 57.34 & 1.5 & 60.17 & 0.63 \\
\hline 62.5 & 50.07 & 0.63 & 59.31 & 1.5 \\
\hline 31.25 & 32.15 & 1.2 & 48.84 & 1.2 \\
\hline 15.63 & 17.63 & 0.72 & 40.75 & 1.5 \\
\hline 7.81 & 7.35 & 2.1 & 37.81 & 1.2 \\
\hline 0 & 0 & 0 & 0 & 0
\end{tabular}

All determinations were carried out in triplicate manner and values are expressed as the mean $\pm \mathrm{SD}$. The $\mathrm{IC}_{50}$ value is defined as the concentration of inhibitor to inhibit $50 \%$ of the enzyme activity under the assayed conditions.

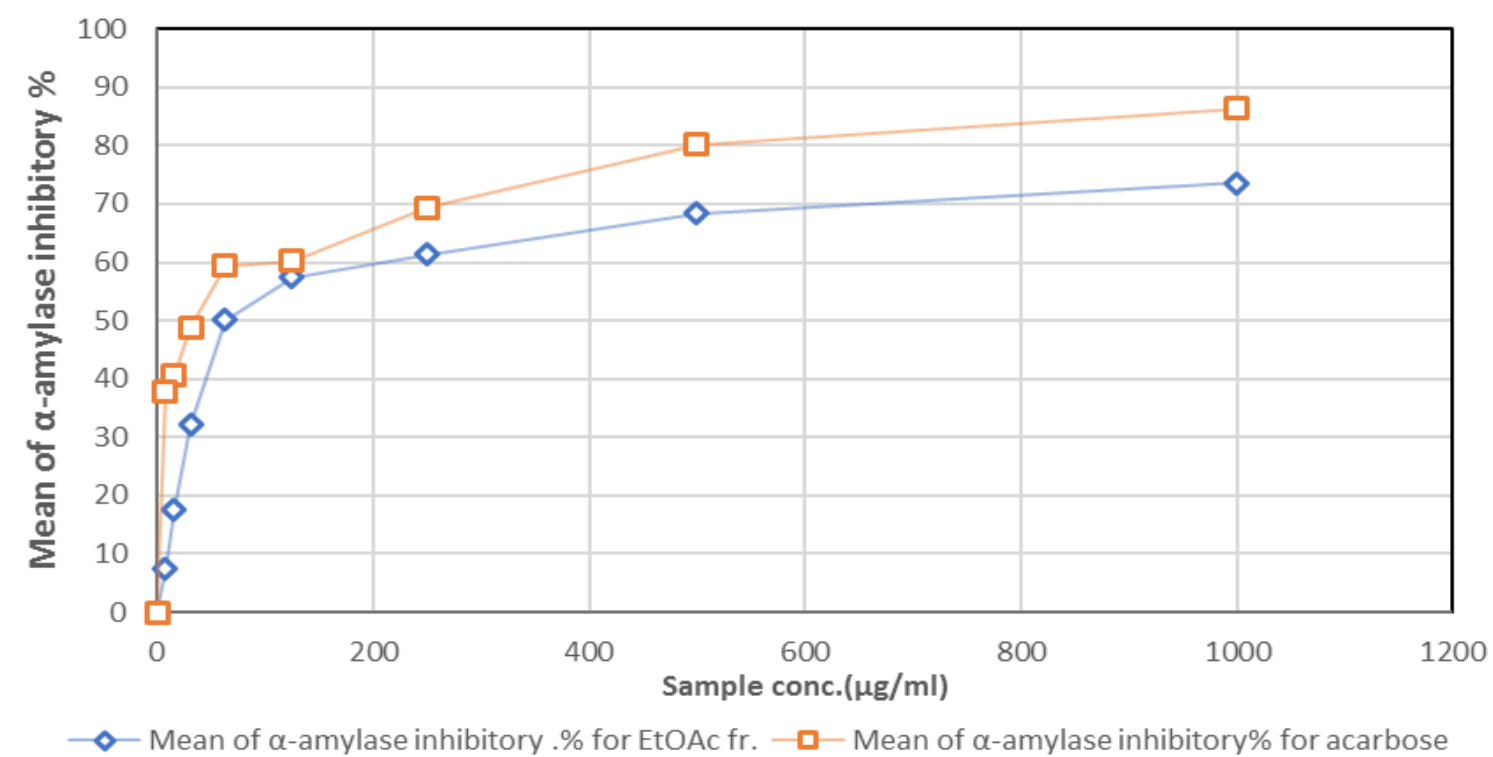

Fig. 6: $\alpha$-amylase inhibitory $\%$ for EtOAc fr. and Acarbose.

\section{Anti-yeast activity:}

The $n$-hexane fraction showed the highest anti-yeast activity among the tested extracts, while compound $\mathbf{3}$ showed the highest anti-yeast activity among the tested compounds (Fig. 7 and Table 7). 


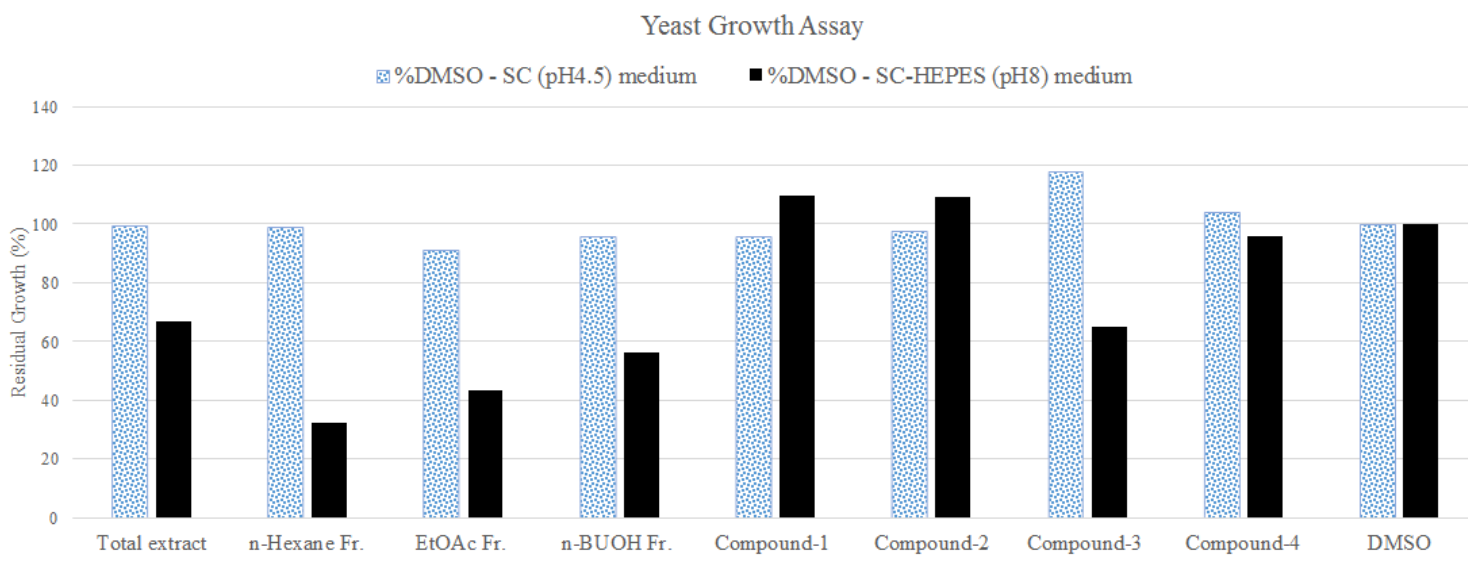

Fig. 7: Anti-yeast activity of A. capillus-veneris total extract, different fractions and compounds.

Table 7: Anti-yeast activity of A. capillus-veneris total extract, different fractions and compounds.

\begin{tabular}{ccccc} 
Sample & $\begin{array}{c}\text { Raw - SC } \\
(\mathrm{pH} 4.5) \\
\text { medium }\end{array}$ & $\begin{array}{c}\text { \%DMSO - SC } \\
(\mathrm{pH} 4.5) \text { medium }\end{array}$ & $\begin{array}{c}\text { Raw - SC- } \\
\text { HEPES } \\
\text { mH8) }\end{array}$ & $\begin{array}{c}\text { \%DMSO - SC- } \\
\text { HEPES (pH8) } \\
\text { medium }\end{array}$ \\
\hline Total extract & 1.0738 & 99.86979167 & 0.6303 & 66.88952563 \\
\hline$n$-Hexane Fr. & 1.065 & 99.05133929 & 0.3037 & 32.22965085 \\
\hline EtOAc Fr. & 0.9816 & 91.29464286 & 0.4083 & 43.33014963 \\
\hline$n$-BuOH Fr. & 1.0333 & 96.1030506 & 0.5301 & 56.25596944 \\
\hline Compound-1 & 1.0334 & 96.11235119 & 1.0334 & 109.667834 \\
\hline Compound-2 & 1.0512 & 97.76785714 & 1.0289 & 109.1902791 \\
\hline Compound-3 & 1.2699 & 118.1082589 & 0.6102 & 64.75644699 \\
\hline Compound-4 & 1.1197 & 104.1387649 & 0.9015 & 95.67016874 \\
\hline DMSO & 1.0752 & 100 & 0.9423 & 100
\end{tabular}

\section{Conclusion}

In this study, phytochemical investigation of the EtOAc fraction resulted in isolation of pinoresinol 4- $O-\beta$-D-glucopyranoside (1) and pterosterone (2), and this is the first time to be isolated from family Pteridaceae, while kampferol-3- $O$ - $\square$-Dglucuronide (3) and quercitin-3-O- $\square$-D-glucopyranoside (4) were isolated from the $n$ butanol fraction and were reported to be isolated previously from the species (Akabori and Hasegawa, 1969; Ibraheim et al., 2011). The EtOAc fraction of A. capillus-veneris fronds and rhizomes showed the highest activity as antidiabetic in comparison to acarbose. On the other hand, the $n$-hexane fraction showed the highest anti-yeast activity. It is recommended that further research is required to explore the other effects of $A$. capillus-veneris growing in Egypt. 


\section{Acknowledgment}

We are grateful to the Egyptian Government for financial support. We also thankful for McKnight Brain Institute, as a portion of this work was performed at the McKnight Brain Institute at the National High Magnetic Field Laboratory's AMRIS Facility (Florida State University, USA) which is supported by National Science Foundation Cooperative Agreement No. DMR-1157490.

\section{REFERENCES}

Ahmadpoor J, Chahardahcheric SV and Setorki M (2019) The protective effect of hydroalcoholic extract of the Southern Maidenhair fern (Adiantum capillusveneris) on the depression and anxiety caused by chronic stress in adult male mice: An experimental randomized study. Iranian Red Crescent Medical Journal 21(3).

Akabori Y and Hasegawa M (1969) Flavonoid pattern in the Pteridaceae II. Flavonoid constituents of the fronds of Adiantum capillus-veneris and A. cuneatum. Shokubutsugaku Zasshi 82(973):294-297.

Al-Snafi AE (2015) The chemical constituents and pharmacological effects of Adiantum capillus-veneris-A review. Asian Journal of Pharmaceutical Science and Technology 5(2):106-111.

Ansari R and Ekhlasi-Kazaj K (2012) Adiantum capillus-veneris. L: Phytochemical constituents, traditional uses and pharmacological properties: A review. Journal of Advanced Scientific Research 3(4):15-20.

Bajguz A, Bąkala I and Talarek M (2015) Ecdysteroids in plants and their pharmacological effects in vertebrates and humans, in Studies in Natural Products Chemistry, Elsevier 45:121-145.

Blunt J, Lane G, Munro M and Russell G (1979) The absolute configuration at C24 of the ecdysteroids dacrysterone, pterosterone and ponasterone C. Australian Journal of Chemistry 32(4):779-782.

Chiba M, Hisada S, Nishibe $S$ and Thieme $H(1980){ }^{13} \mathrm{C}$ NMR analysis of symplocosin and (+)-epipinoresinol glucoside. Phytochemistry 19(2):335-336.

Coll J, Reixach N, Sanchez-Baeza F, Casas J and Camps F (1994) New ecdysteroids from Polypodium vulgare. Tetrahedron 50(24):7247-7252.

Diep TT, Van Kiem P, Dong NT, Tung NH, Bang BT, Van Minh C and Braca A (2007) Pinoresinol and 3,4',5,7-tetrahydroxy-3'-methoxyflavanone from the fruits of Silybum marianum (L.) Gaertn. Vietnam Journal of Chemistry 45(2):219-222.

Dziwornu GA, Caira MR, Mare J-Adl, Edkins AL, Bolton JJ, Beukes DR and Sunassee SN (2017) Isolation, characterization and antiproliferative activity of new metabolites from the South African Endemic Red Algal Species Laurencia alfredensis. Molecules 22(4):513-529.

Harborne JB (1994) The flavonoids advances in research since 1986, Taylor \& Francis. 
Ibraheim ZZ, Ahmed AS and Gouda YG (2011) Phytochemical and biological studies of Adiantum capillus-veneris L. Saudi Pharmaceutical Journal 19(2):6574.

Kajdžanoska M, Gjamovski $V$ and Stefova $M$ (2010) HPLC-DAD-ESI-MS ${ }^{\mathrm{n}}$ identification of phenolic compounds in cultivated strawberries from Macedonia. Macedonian Journal of Chemistry and Chemical Engineering 29(2):181-194.

Liu H, Mou Y, Zhao J, Wang J, Zhou L, Wang M, Wang D, Han J, Yu Z and Yang F (2010) Flavonoids from Halostachys caspica and their antimicrobial and antioxidant activities. Molecules 15(11):7933-7945.

Narkhede M, Ajimire P, Wagh A, Mohan M and Shivashanmugam A (2011) In vitro antidiabetic activity of Caesalpina digyna (R.) methanol root extract. Asian Journal of Plant Science and Research 1(2):101-106.

Nawwar M, Souleman A, Buddrus J and Linscheid M (1984) Flavonoids of the flowers of Tamarix nilotica. Phytochemistry 23(10):2347-2349.

Nazim M, Aslam M and Chaudhary SS (2018) Hansraj (Adiantum capillus-veneris)A review. Journal of Drug Delivery and Therapeutics 8(5-s):105-109.

Nishimoto N, Shiobara Y, Fujino M, Inoue S-S, Takemoto T, De Oliveira F, Akisue G, Akisue MK, Hashimoto G and Tanaka O (1987) Ecdysteroids from Pfaffia iresinoides and reassignment of some ${ }^{13} \mathrm{CNMR}$ chemical shifts. Phytochemistry 29(9):2505-2507.

Ohta S, Guo J-R, Hiraga $Y$ and Suga T (1996) 24-Epi-pterosterone: A novel phytoecdysone from the roots of Athyrium yokoscense. Phytochemistry 41(3):745-747.

Ouyang M-A, Wein Y-S, Zhang Z-K and Kuo Y-H (2007) Inhibitory activity against tobacco mosaic virus (TMV) replication of pinoresinol and syringaresinol lignans and their glycosides from the root of Rhus javanica var. roxburghiana. Journal of Agricultural and Food Chemistry 55(16):6460-6465.

Rasouli H, Hosseini-Ghazvini SM-B, Adibi H, Khodarahmi R (2017) Differential $\alpha$ amylase/ $\alpha$-glucosidase inhibitory activities of plant-derived phenolic compounds: a virtual screening perspective for the treatment of obesity and diabetes. Food and Function 8(5):1942-1954.

Rastogi S, Pandey MM and Rawat AKS (2018) Ethnopharmacological uses, phytochemistry and pharmacology of genus Adiantum: A comprehensive review. Journal of ethnopharmacology 215:101-119.

Shai L, Magano S, Lebelo S and Mogale A (2011) Inhibitory effects of five medicinal plants on rat alpha-glucosidase: Comparison with their effects on yeast alphaglucosidase. Journal of Medicinal Plants Research 5(13):2863-2867.

Smith AM, Heisler LE, Mellor J, Kaper F, Thompson MJ, Chee M, Roth FP, Giaever $\mathbf{G}$ and Nislow $\mathbf{C}$ (2009) Quantitative phenotyping via deep barcode sequencing. Genome Research 19(10):1836-1842.

Subramoniam A (2016) Anti-Diabetes Mellitus Plants: Active Principles, Mechanisms of Action and Sustainable Utilization, CRC Press. 
Wikul A, Damsud T, Kataoka K, Phuwapraisirisan P (2012) (+)-Pinoresinol is a putative hypoglycemic agent in defatted sesame (Sesamum indicum) seeds though inhibiting $\alpha$-glucosidase. Bioorganic and Medicinal Chemistry Letters 22(16):5215-5217.

Worawalai W, Khongchai P, Surachaitanawat N and Phuwapraisirisan P (2016) Synthesis of furofuran lignans as antidiabetic agents simultaneously achieved by inhibiting $\alpha$-glucosidase and free radical. Archives of Pharmacal Research 39(10):1370-1381.

Yue Z, Qin H, Li Y, Sun Y, Wang Z, Yang T, Liu L, Wang M, Feng F and Mei Q (2013) Chemical constituents of the root of Jasminum giraldii. Molecules 18(4):4766-4775.

Yumkham SD, Elangbam M, Nongmaithem R, Naorem PD and Singh PK (2018) Maiden hair ferns (Adiantum L., Pteridaceae-Vittarioideae) of North East India: diversity, phytochemistry and utilization. Genetic Resources and Crop Evolution 65(4):1269-1280.

Zhang X, Chen H-L, Hong L, Xu L-L, Gong X-W, Zhu D-L, Xu X-H, Zhao W, Wang $F$ and Yang X-L (2019) Three new hopane-type triterpenoids from the aerial part of Adiantum capillus-veneris and their antimicrobial activities. Fitoterapia 133:146-149.

Zhou Y, Wang W, Tang L, Yan X-g, Shi L-y, Wang Y-q and Feng B-m (2009) Lignan and flavonoid glycosides from Urtica laetevirens Maxim. Journal of Natural Medicines 63(1):100-101. 


\author{
الملخص العربي \\ "دراسة فيتوكيميائية وبيولوجية لتبات كزبرة البئر النامي في مصر" \\ محمود محمد عبدالهادي سلام، أحمد عز الدين مصطفى ، عزت عبد الظاهر جنيدي، سعيد قطب اسماعيل \\ قسم العقاقير ـ كلية الصيدلة (بنين) - جامعة الأزهر ـ القاهرة ـ مصر.
}

" يعتبر نبات كزبرة البئر أحد النباتات الوعائية اللابذرية التابعة لجنس البرشاوشان، كما ينتمي إلى طائفة

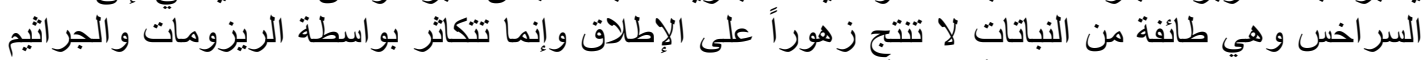

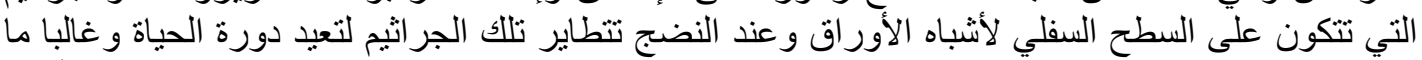

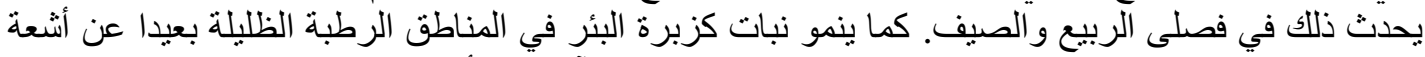

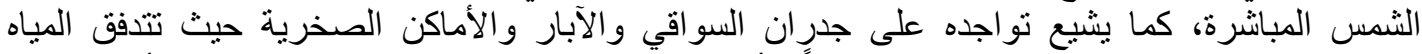

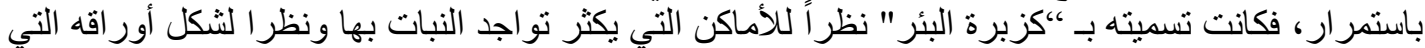
تشبه أور اق نبات الكزبرة التابع للعائلة الخيمية.

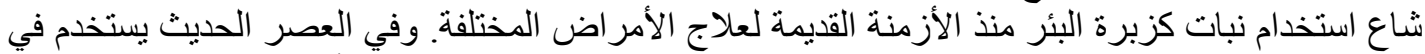

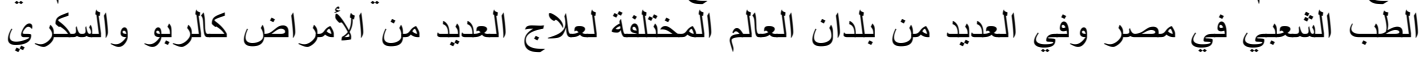

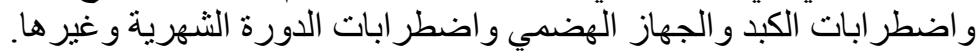

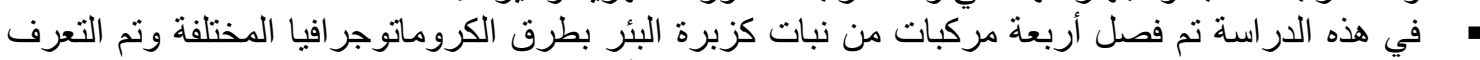

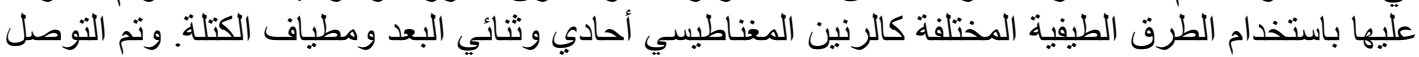

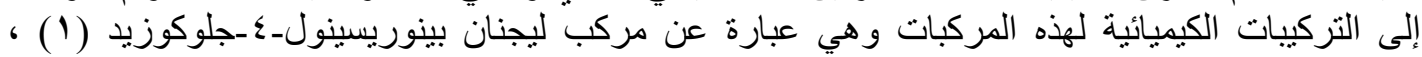

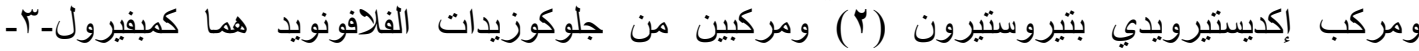
جلوكورونيد (r) وكويرسيتين-؟ -جلوكوزيد (4).

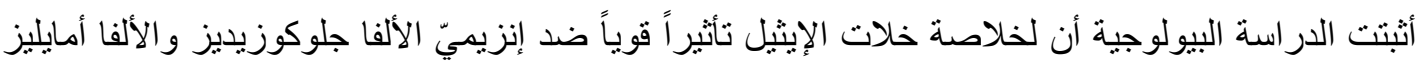

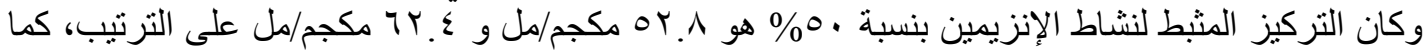
أظهرت الدراسة أيضا أن لخلاصة الهكسان التأثير الأقوي من بين خين خلاصدات النبات المختلفة كمضاد 